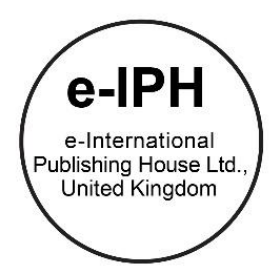

\title{
The Strategy of Drama Series "Lonceng Cinta" in Increasing Public Interest Through Social Media Twitter
}

\author{
Hadiono Afdjani, Daniel Simanjuntak \\ Universitas Budi Luhur, Jakarta, Indonesia \\ hadiono.afdjani@budiluhur.ac.id, danielsimanjuntak1987@gmail.com
}

\begin{abstract}
This study aims to find out how the promotion strategy of television drama series "India Lonceng Cinta" through Twitter conducted by social media team ANTV. The focus of the problem is on the use of social media twitter @seriesANTV and @whatsonANTV in promoting the Indian drama series "Lonceng Cinta" to the public. The development of twitter today, not only as a social media, but ANTV use it as a media promotion of impressions to the people of Indonesia. Theories used are New Media theory and Marketing Communication theory. The paradigm of the research is the postpositivism paradigm, the qualitative approach and the method used is the interistic approach, that is expressing how the social media team strategy in promoting drama series "Lonceng Cinta" using twitter.
\end{abstract}

Keywords: Promotion, Social Media, Twitter, Television Program, Marketing Communications

eISSN: 2398-4287 @ 2020. The Authors. Published for AMER ABRA cE-Bs by e-International Publishing House, Ltd., UK. This is an open access article under the CC BYNC-ND license (http://creativecommons.org/licenses/by-nc-nd/4.0/). Peer-review under responsibility of AMER (Association of Malaysian Environment-Behaviour Researchers), ABRA (Association of Behavioural Researchers on Asians) and cE-Bs (Centre for Environment-Behaviour Studies), Faculty of Architecture, Planning \& Surveying, Universiti Teknologi MARA, Malaysia.

DOI: https://doi.org/10.21834/ebpj.v5iSI1.2296

\subsection{Introduction}

The Ministry of Communication and Information (Kemenkominfo) revealed that internet users in Indonesia currently reach 63 million people, and 95 per cent of them used the internet to access social networks. In the global era, the development of telecommunication and information (IT) is very rapid. Technology closes the distance in communication which certainly internet as one of the communication media. Twitter became one of the most social media widely used in society and employed by many companies as a media campaign, including ANTV that used Twitter as promotional media for all its shows in order to be watched by more people (Zarela, 2010). The survey institute of AC Nielsen provides data in the form of rating and share of television programs. The data becomes a reference for advertisers, in how to place an advertisement on ANTV. The drama series Lonceng Cinta, if the rating is high, then it will undoubtedly be an attraction for advertisers to buy advertising slots on the show, thus providing a substantial income for the company. The promotion through social media requires precision in showing the promo of the program. The promotion itself is not only seen from the intensity of which is a lot of promotional programs, but the accuracy of the promotional placement is more useful to build public awareness about the programs in ANTV.

\subsection{Methodology}

The researchers chose to use qualitative research methods to determine how to find, collect, process, and analyze the data results. This qualitative research can be used to understand social interaction, for example, by in-depth interviews, in order to find clear patterns. This study used qualitative methods with descriptive design, i.e. the research that gives a precise description of a particular individual or group about the circumstances and symptoms that occurred (Creswell, 1994). The technique of collecting data in this research is done by using data obtained from some source that is primary data and secondary data. Primary data is data obtained by the author with a specific purpose related to research. While secondary data is data available and collected by the author to support and still relevant to

eISSN: 2398-4287 ( 2020. The Authors. Published for AMER ABRA cE-Bs by e-International Publishing House, Ltd., UK. This is an open access article under the CC BYNC-ND license (http://creativecommons.org/licenses/by-nc-nd/4.0/). Peer-review under responsibility of AMER (Association of Malaysian Environment-Behaviour Researchers), ABRA (Association of Behavioural Researchers on Asians) and cE-Bs (Centre for Environment-Behaviour Studies), Faculty of Architecture, Planning \& Surveying, Universiti Teknologi MARA, Malaysia.

DOI: https://doi.org/10.21834/ebpj.v5iSI1.2296 
the purpose of research (Moleong, 2010). Theories used are New Media theory and Marketing Communication theory. The paradigm of the research is the post-positivism paradigm, the qualitative approach and the method used is the interistic approach, that is expressing how the social media team strategy in promoting drama series "Lonceng Cinta" using twitter.

\subsection{Research Result and Discussion}

At the end of 2013, ANTV began to promote its official account in social media. In 2014, Twitter became the first choice to be employed and followed with other social media to share all the information that must be conveyed to people, especially lovers of ANTV. Initially, ANTV made the "special" program to be viral or as a trending topic, but the policy had changed at the end of 2016 that the target of ANTV was to become national TV no.1 in Indonesia, which made almost all the morning up tonight program "must" enter the trending Topic (on Twitter). ANTV has had not only Twitter active accounts but also Facebook, Instagram, Google+, and Youtube.

The basic reason to use social media as communication media with the audience of drama series Lonceng Cinta was to get feedback about the program which then develop into interaction media (engagement) and see another "insight" as input sources. Especially Lonceng Cinta drama that was not too difficult to penetrate in the beginning because the program story was unique and starring by "young" and good looking actors. Thus it is included as the fast received program by people which was reflected from the rating and the number interest of the audience who commented in Social Media to every post of Lonceng Cinta.

Twitter is one of the social media that is widely used by internet users. The simple reason is that the use of Twitter is very easy and able to reach various societies. For this reason, many TV shows are trying to create a Twitter account for promotional and information media to viewers and attract people interested in the program. ANTV is also one of the users of social media Twitter to make a lot of people interested in the show, in particular, of Indian drama series.

Advertising programs through social media was able to help viewers and followers to directly interact with ANTV, not only to help them voice their opinions directly either suggestions or criticisms but also provide a sense of personal touch with ANTV. For example, if ANTV released a new series or program and promoted via Twitter, they would invite the followers to re-tweet and offered gifts such as meeting the cast of the drama series they liked. ANTV also asked the follower or audience to voice their opinions about ANTV programs. Those actions would make the ads more interactive and gave reasons for people to stay watching ANTV programs. Currently, one of the tools used by ANTV to increase promotional activities was social networking Twitter. Social network Twitter had provided an important role to build a relationship with the loyal audience of ANTV personally.

Some of the benchmarks of the successful promotional strategy through Twitter, according to Eko Yuwono (Marketing Communication Manager of ANTV) were:

- $\quad$ Engagement Number/ high interaction (comment). (> 100/post)

- $\quad$ High impression rate ( $>100 \mathrm{~K}$ )

- $\quad$ The negative comments are the low number from the follower.

- Viral (trending), hashtag program, footage of the scene, the artist jokes that went viral on the internet by tagging ANTV account.

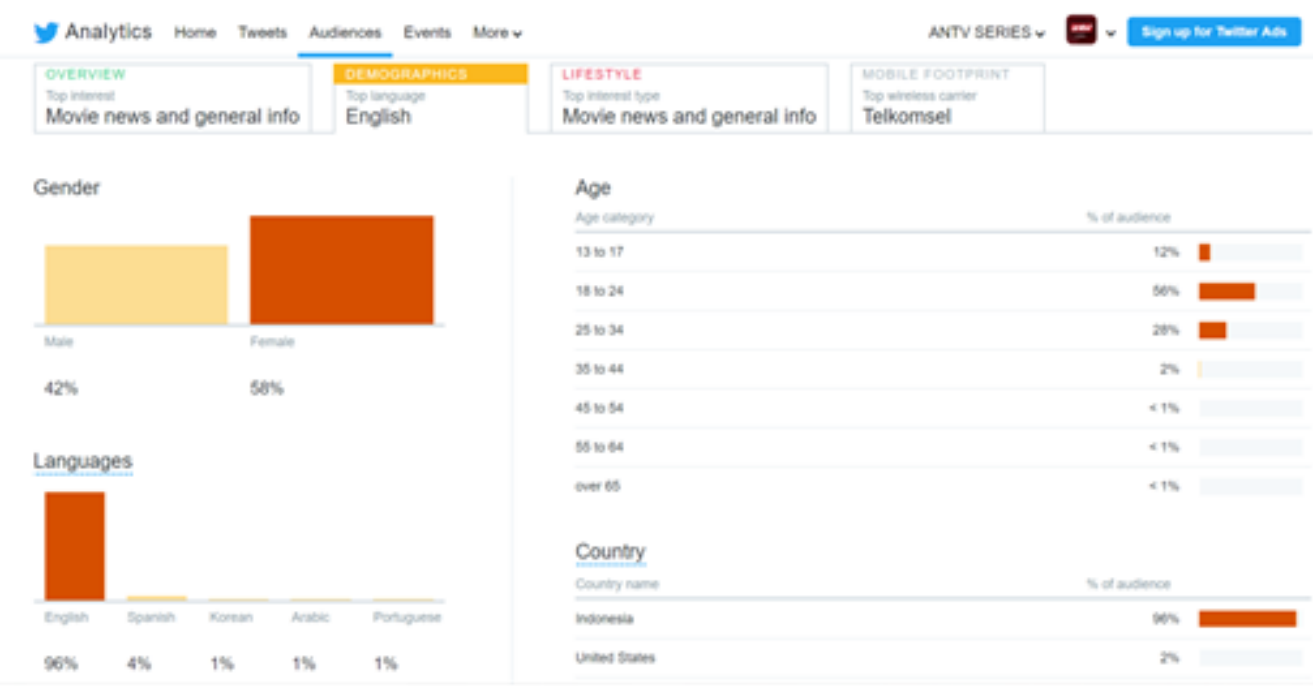

Foto 1: Demographic data of Twitter follower account @seriesANTV

Those can be known from the evaluation that was always done to find out the results of the promotion through Twitter. The evaluations usually were done in routine by monitoring the statistics of each account, an increase of follower number, engagement, and demographic. Social media was also a bridge of Lonceng Cinta fans to give aspirations, inputs, and even complaints. For the correlation of the rating performance so far, there had been no assessment tool that can be used accurately. However, in some cases of Indian programs, it was quite reflected from the feedback when social media team posted the information (videos, fotos, or text). The number of Views and Number of Comments was a reflection on whether the program would be quite attractive or not in the future; thus it predicted the program 
to be still popular or not for the audience. ANTV used two Twitter accounts daily to connect with its loyal followers intensely; @seriesANTV and @whatsonANTV that run by a team consisting of several people.

Seen from the foto above, the follower number of Twitter account @seriesANTV was 219K which meant about 219 thousand followers. Most of the followers were female which about $58 \%$ of total followers account @seriesANTV, and male followers were about $42 \%$ of total followers account @seriesANTV. Of the total follower account at @seriesANTV, it was dominated by people aged 18-24 years. They were the type of viewers who most often used social media in their daily life who almost every time hold the gadget and spent the time to be active in social media. Currently, social media especially Twitter that used by the social media team of ANTV, was part of the development in sharing information. In previous time, technology media that could deliver messages to millions of people efficiently was through television or newspapers. Its disadvantage in conveying the message to millions of people was using high cost and unclearly directed to the desired target. Media users also become passive parties by simply accepting all the provided information without being able to choose. But in the present era, message delivery becomes more developed. Ease of access to the internet makes information widely and quickly spread to millions of internet users. In spreading the message, it also does not need to use expensive charge.

This ease was added with the advantages of the internet that provide a variety of information for each user, particularly. Users can actively access the information they want. This is the advantage of the internet compared to other promotional media. This internet advantage can then be maximized by using social media interactively in order for the promotion to be more effective. This was employed by ANTV while using social media Twitter to provide interesting info for the loyal audience of ANTV.

There were several reasons for ANTV to use social media, especially Twitter, among them were:

1. Twitter is able to improve relationships between companies and society.

Twitter is able to change the style of communication to become more interactive and participative; this caused the relationship between ANTV and the audience or the community became more intense, more personal, and equal (horizontal). Twitter allows viewers of Indian drama seriesLonceng Cinta to comment directly with the airing program on ANTV or things going on the program. By creating Twitter account @seriesANTV and @whatsonANTV, the administrator of ANTV social media was able to communicate with the audience easily and closely. The interaction between the social media team (representing ANTV Company) and the loyal audiences of the Indian drama series Lonceng Cinta became a close relationship; the audience always asks about drama series Lonceng Cinta and then the social media team will provide the answer.

\section{Twitter Enhances Brand Awareness and User Engagement.}

With the social media Twitter @seriesANTV and @whatsonANTV, the ANTV social media teams were able to gather the communities of Indian drama series lovers, especially the drama series Lonceng Cinta in one particular place; this of course facilitated the ANTV social team to do the promotion or at least interact with the communities of Indian drama series lovers. As loyal audiences of Indian drama series, they felt more involved in many things, because their suggestions, criticisms, and desires were more easily heard. Thus one of the usages of social media is to increase brand awareness and user engagement.

3. Twitter is able to Lower Promotion Costs.

Today the promotion can be done more simply and cost-effectively by using Twitter. Social media, in particular Twitter, improves the efficiency of ANTV such as reducing the promotion cost because with social media every user is a "spokesman", reducing the research costs since social media makes it easy to conduct a survey directly to the communities of Indian drama series lovers, and getting advice directly from loyal audiences of ANTV Indian dramas.

To get the targeted results regarding the promotion of drama series Lonceng Cinta, the social media team had done some strategies. The activity of ANTV social media team did in improving relationships with the drama series audience of Lonceng Cinta through Twitter, were as follows:

\section{Creating an Attractive Live Tweeting.}

The ANTV social media team made communicative and attractive Live Tweeting during the airing of Indian drama series of Lonceng Cinta. Apparently, this affected audience euphoria. The conversation during the program is believed to be as one of the magnets that are able to attract audience curiosity. The audience would like to hear the response from the TV show maker via communication on the Twitter account, especially if the Twitter account of the TV show is also followed.

\section{ANTV Series $\otimes$ SeriesANTV - Jun 11}

Kalo pragya sama purab nanti mimin sm siapa dong? \#LONCENGCINTAEPS262

\section{Spica Sanggel @spicasanggel}

Terkadang kalau begini gw berharap pragya sm purab aja

\#LONCENGCINTAEPS262 kayaknya jauh lebih tenang dr pd sm abhi dramanya ga slesai"

Foto 2: Tweets from Follower of @seriesANTV when the drama was airing at ANTV 


\section{Creating Quiz (Prize Quiz)}

Quiz (prize quiz) usually is done to increase engagement and people aware of the program. The form of the quiz is diverse such as questions about the program content, selfie quiz with the background program (Lonceng Cinta), up to the best comments of the program.

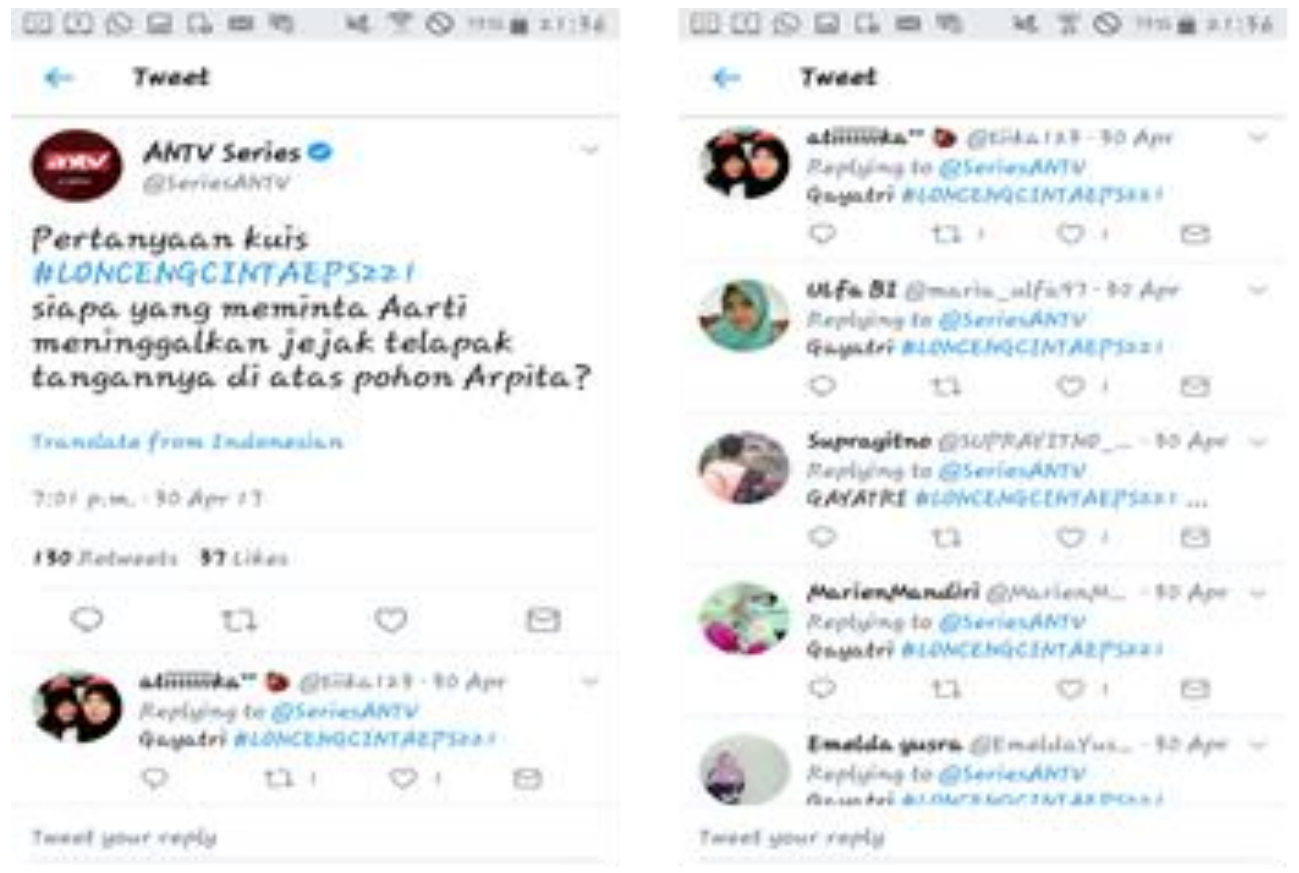

Foto3: Lonceng Cinta Quiz provided by ANTV via Twitter

\section{Creating Daily Synopsis}

By creating a daily synopsis, the synopsis is usually posted a day before the running program or after the program finished. The social media team always posted the episode synopsis that would air along with the time and date of the drama series Lonceng Cinta to inform Twitter users about the series screening schedule. The team worked together to make sure to announce the screening schedule on Twitter at the prime time so that the number of Twitter users who get the information can be maximized

\section{Making Promo Video}

And also with episodic promos (usually 15-30 seconds videos) posted on Twitter, FB \& Instagram account. The video was contained a short trailer of the episodes that would be aired on that day.

\section{Anticipating Negative Comments}

ANTV's social media teams used Twitter accounts wisely to anticipate erroneous social assumptions that widespread in society. For example, if the plot of the drama series Lonceng Cinta was complicated, the social media team would explain it through Twitter that the story was originally developed based on the true story experienced by the story narrator. Thus, TV show audiences would certainly feel more appreciated and cared to for their existences.

Indonesian people love drama series that tells about daily life; love stories, domestic conflicts, and inter-family crimes, for example, by watching the drama series every day on television. In the era that increasingly developed, the longer people do communication, the way more developed its way, also television viewers in Indonesia who use Twitter. The changes way of communication today was because of the emergence of social media. In every day, the users of social media were increasingly rapid with the growing number of new social media account along with the more easy access to the internet in homes, as well as the development of smartphone and tablets technology. Today, spreading information is no longer by mouth to mouth, but through social media. It even has a greater impact because of its coverage that connects the entire world through the network. The growing popularity of social media is so rapid since it is very effective and efficient in spreading information and minimizes misunderstanding in delivering messages. Social media is a new medium, as in the theory of new media offered by Pierre Levy.

Clearly, new media has the speed to make the interaction more efficient, cheaper, and faster to get the latest information and most updated information. The spot of internet connection network is only if the internet network runs smoothly and quickly that then the information submitted quickly to readers, there must also be internet connection wherever located with new media (online media). As a medium of communication, Twitter has an important role as a channel to communicate the message from sources/communicator to the receiver of ANTV audience. Twitter is a medium of transactional communication; in other words, there is intensive interaction between individuals (continuously) and feedback from individuals in each interaction.

Marketing communication has a very important role, as Philip Kotler \& Kevin Lane Killer stated that in an organization or marketing communications, marketing has a role to provide information, persuade, and remind consumers directly or indirectly about the products and brands (Kotler,2009:34). Marketing communications carry out many functions to the consumer (ANTV audience) or target market, in particular, to tell and show about how and why the product is used, who the target market is, and where and when the product 
can be obtained. The environment of marketing communications in line with the development of communication technology process has also changed, as the recent condition where the internet developed massively. Thus, this, of course, will also affect the consumer in obtaining product information.

\subsection{Conclusion}

The usage of Twitter allowed follower of @seriesANTV and @whatsonANTV to make changes (updates), such as information, status, content, etc., that online at any time by using the internet as delivery media. The thing that made social networking be in demand was that it was possible to connect with many parties without any obstacle such as distance and time, it only required minimal effort and resources, that is, the availability of IT media and internet connection.

The phenomenon of interaction through social media was developing that should be used as well as possible for promotions, especially the promotion of another Indian drama series that aired on ANTV. In spreading information, it was no longer done in a passive way that reduced the confidence level of the loyal audience of ANTV, but its delivery was developed to be more interactive in order to increase audience confidence level. By using social media appropriately, it had the potential to increase people interest in watching especially the use of social media Twitter that read and followed its social media account. The appropriate usage of social media was by using persuasive and emotional attachment so that it will increase the followers' trust of the account to the information given.

\section{Acknowledgments}

The authors thank ANTV, Jakarta, Indonesia, as a place of research author. Also, to all informants in ANTV who have provided information through interviews for this research.

\section{References}

Creswell, J. W. (1994). Research design: Qualitative and quantitative approach. London: Publications.

Lexy, J. M. (2010). Qualitative research methodology. Bandung: Remaja Rosdakarya.

Kotler, P., \& Keller, K., L. (2009). Marketing Management. Jakarta:Erlangg

Zarela, D. (2010). The Social Media Marketing Book. Jakarta: PT Serambi Ilmu Semesta. 